\title{
PENGARUH JUMLAH PENDUDUK DAN PENGELUARAN PEMERINTAH TERHADAP PERTUMBUHAN EKONOMI DI SUMATERA UTARA
}

\author{
Azwar Hamid \\ IAIN Padangsidimpuan \\ Jalan T. Rizal Nurdin Km. 4,5 Sihitang, Padangsidimpuan \\ Email : zwar.hamidnasution@gmail.com
}

\begin{abstract}
Abstrak,
Jumlah penduduk dan pengeluaran pemerintah merupakan salah satu faktor yang mempengaruhi pertumbuhan ekonomi, tapi jika jumlah penduduknya melonjak cepat justeru akan penghambat pembangunan ekonomi. Begitu juga pengeluaran pemerintah atau anggaran belanja Negara yang terus naik untuk manajemen pemenuhan kebutuhan publik akan mempengaruhi pertumbuhan ekonomi. Sebab itu penting untuk diketahui apakah meningkatnya jumlah penduduk dan naiknya anggaran belanja Negara yang terus fluktuasi setiap tahunnya mempengaruhi terhadap pertumbuhan ekonomi disumatera utara. Penelitian ini adalah penelitian kuantitatif dengan pendekatan deskriftif. Metode ini disebut kuantitatif karena data penelitian berupa angka-angka dan analisis menggunakan statistik SPSS 23. Teknik yang digunakan dalam penarikan sampel adalah teknik purposive sampling dengan sampel 30 sampel.
\end{abstract}

Kata kunci: Jumlah Penduduk, Pengeluaran Pemerintah, Pertumbuhan Ekonomi.

\begin{abstract}
,
Population and government spending are one of the factors that influence economic growth, but if the population rises rapidly it will actually inhibit economic development. Likewise, government spending or budget State rising to meet the needs of public management will affect economic growth. Because it is important to know whether the increase in population and the increase in the State budget which continues to fluctuate every year affects the economic growth in North Sumatra. This research is a quantitative research with descriptive approach. This method is called quantitative because the research data in the form of numbers and analysis using SPSS 23 statistics. The technique used in sampling is purposive sampling technique with a sample of 30 samples.
\end{abstract}

Keywords: Population, Government Expenditure, Economic Growth. 


\section{PENDAHULUAN}

Jumlah penduduk dan pengeluaran pemerintah merupakan salah satu faktor yang mempengaruhi pertumbuhan ekonomi, dan mampu menunjang keberhasilan dalam pembangunan (M. Umer, 2013). Namun, jika jumlah penduduknya melonjak cepat justeru akan penghambat pembangunan ekonomi (Iskandar, 2013). Begitu juga pengeluaran pemerintah atau anggaran belanja Negara yang terus naik untuk manajemen pemenuhan kebutuhan publik juga penghambat pertumbuhan ekonomi (M.Umer Chapra, 2000). Misalkan, meningkatnya anggaran biaya langsung dan anggaran biaya tidak langsung yang terdiri dari belanja pegawai, bantuan sosial, belanja hibah dan lain sebagainya.

Sumatera utara merupakan salah satu wilayah dengan populasi yang relatif tinggi setelah pulau Jawa. Data Statistik menunjukkan perkembangan jumlah penduduk dari tahun 1987 sampai 2016 mengalami penaikan ditiap tahunnya (BPS Sumut, 2016). Pada tahun 1987 perkembangan jumlah penduduk di Sumatera Utara sebesar 9.901.862 juta jiwa, dan mengalami peningkatan di tahun 1988 sampai 1989 sebesar 10.330.091 juta jiwa. Kemudian mengalami penurunan di tahun 1990 sebesar 10.256.027 juta jiwa.

Pada tahun 1991 perkembangan jumlah penduduk di Sumatera Utara mengalami peningkatan sebesar 10.572.769 juta jiwa sampai tahun 1999 sebesar 11.955.400 juta jiwa. Tahun 2000 kembali mengalami penurunan sebesar 11.513.973 juta jiwa, dan meningkat kembali pada tahun 2001 sebesar 11.722.397 juta jiwa sampai tahun 2009 sebesar 13.248.386 juta jiwa. Pada tahun 2010 jumlah penduduk Sumatera Utara menurun sebesar 12.982.204 juta jiwa. Hal ini disebabkan karena pemerintahan orde baru menetapkan kebijakan untuk menekan laju pertumbuhan penduduk dengan melaksanakan program keluarga berencana. Dengan diterapkannya hal tersebut laju pertumbuhan penduduk di Indonesia termasuk Sumatera Utara dan wilayah lainnya berhasil diatasi, namun di tahun 2011 kembali mengalami peningkatan sampai 2016 sebesar 14.102.911 juta jiwa. Naiknya laju pertumbuhan penduduk ini diakibatkan karena adanya hambatan dalam nilai sosial budaya masyarakat yang masih tradisional. Kenaikan di tahun ini dapat memicu timbulnya kemiskinan, pengangguran, putus sekolah serta permasalahan tekait ketahanan dan kesejahteraan (Sumut, 2017).

Seperti halnya yang terjadi di Sumatera Utara, belanja Negaranya juga fluktuasi ditiap tahunnya. Pada tahun 1987, laju perkembangan pengeluaran pemerintah Sumatera Utara sebesar 205.200 juta, dan mengalami peningkatan pada tahun 1988 sebesar 290.355 juta sampai tahun 1997 sebesar 771.000 juta. Di tahun 1998 pengeluaran pemerintah cenderung mengalami penurunan dari tahun-tahun sebelumnya yaitu sebesar 342.600 juta sampai tahun 2000 sebesar 416.800 juta. Keadaan ini disebabkan karena krisis ekonomi global yang dimulai dari krisis finansial yang mempengaruhi perekonomian dunia. Pada keadaan ini pemerintah diharuskan merumuskan instrument dalam kebijakan fiskal terutama dalam 
penerimaan pengeluaran dan dampaknya terhadap perekonomian untuk mengurangi tingkat pengangguran dan inflasi serta nilai tukar yang lemah(Sumut, 2017).

Pada tahun 2001, pengeluaran pemerintah setelah krisis cenderung mulai membaik sebesar 916.200 juta sampai tahun 2013 sebesar 8.866.900 juta. Peningkatan ini didukung oleh peran pemerintah dalam mengarahkan perekonomian yang positif dengan berbagai cara dan kebijakan-kebijakan dengan menjaga daya tahan perusahaan atau sektor usaha serta menciptakan kesempatan kerja untuk mempercepat pertumbuhan ekonomi. Namun pada tahun 2014 pengeluaran pemerintah mengalami penurunan sebesar 8.525.300 juta sampai 2015 sebesar 8.679.300 juta. Dan di tahun 2016 pengeluaran pemerintah kembali meningkat sebesar 9.476.420 juta, ini disebabkan karena meningkatnya anggaran biaya langsung dan anggaran biaya tidak langsung yang terdiri dari belanja pegawai, bantuan sosial, belanja hibah dan lainnya.

Dari data yang ada di atas, penting untuk diketahui apakah meningkatnya jumlah penduduk dan naiknya anggaran belanja Negara yang terus fluktuasi setiap tahunnya mempengaruhi terhadap pertumbuhan ekonomi disumatera utara.

\section{TINJAUAN TEORITIK}

\section{Pertumbuhan Ekonomi}

Pertumbuhan ekonomi adalah salah satu indikator yang sangat penting dalam melakukan analisis tentang pembangunan ekonomi yang terjadi pada suatu Negara, yang menunjukkan sejauh mana aktivitas perekonomian akan menghasilkan tambahan pendapatan masyarakat pada periode tertentu. Karena pada dasarnya aktivitas perekonomian adalah suatu proses pembangunan faktor-faktor produksi untuk menghasilkan output, dan akan menghasilkan suatu aliran balas jasa terhadap faktor produksi yang diiliki oleh masyarakat. Dengan pertumbuhan ekonomi yang tinggi dalam jangka panjang diharapkan pendapatan masyarakat sebagai pemilik faktor produksi juga akan turut meningkat. Indikator yang digunakan untuk mengukur pertumbuhan ekonomi adalah tingkat pertumbuhan Produck Domestik Bruto (PDB) di tingkat Domestik dan PDRB atau Produck Domestik Regional Bruto untuk tingkat wilayah atau regional.

Ada beberapa faktor-faktor yang menentukan pertumbuhan ekonomi suatu negara, diantaranya adalah tanah dan kekayaan alam, jumlah serta mutu penduduk dan tenaga kerja serta modal dan teknologi. Bila keempat faktor ini lengkap dan bisa diatur oleh pemerintah, maka pertumbuhan ekonomi akan semakin lancar dan membaik. 


\section{Jumlah Penduduk}

Penduduk berfungsi ganda dalam perekonomian, dalam konteks pasar penduduk berada di sisi permintaan maupun di sisi penawaran. Di sisi permintaan, penduduk adalah konsumen atau sumber permintaan akan barang-barang dan jasa. Di sisi penawaran, penduduk adalah produsen atau pedagang dan tenaga kerja. Namun, Dalam konteks pembangunan, pandangan terhadap penduduk terpecah dua, ada yang menganggapnya sebagai penghambat pembangunan, namun ada pula yang menganggapnya sebagai pendorong pembangunan.

Perkembangan penduduk yang tinggi selanjutnya menghambat Negara berkembang untuk mencapai salah satu tujuan penting pembangunan ekonomi yaitu pemerataan pendapatan. Dengan pertambahan jumlah penduduk tersebut maka akan menyebabkan jurang perbedaan yang telah ada diantara masyarakat bertambah lebar. Sebabnya mengapa para ahli ekonomi sangat tertarik kepada masalah kependudukan adalah karena penduduk itulah yang melakukan produksi maupun konsumsi, penduduk itulah subjek ekonomi. Jumlah serta mutu (kuantitas serta kualitas) penduduk suatu Negeri merupakan unsur penentu yang penting bagi kemampuan memproduksi serta standar hidup suatu negara. Namun demikian, sebab yang paling utama mengapa masalah penduduk itu sangat manarik perhatian para ahli ekonomi adalah karena penduduk itu merupakan sumber tenaga kerja, human resources, disamping sumber faktor produksi managerial skill.

\section{Pengeluaran Pemerintah}

Pengeluaran pemerintah merupakan suatu tindakan pemerintah untuk mengatur jalannya perekonomian dengan cara menentukan besarnya penerimaan dan pengeluaran pemerintah tiap tahunnya yang tercermin dalam dokumen APBN untuk nasional dan APBD untuk daerah/regional. Pemerintah haruslah berbelanja sesuai dengan pendapatan, keadaan inilah yang dinamakan dengan anggaran belanja berimbang. Namun apabila belanja perintah melebihi penerimaan, sehingga mengharuskan pemerintah meminjam dari masyarakat atau mencetak uang baru, dan berbelanja melebihi pendapatan dari pajak baik untuk mengatasi pengangguran, kemiskinan, musibah dan lainnya. Keadaan inilah yang menimbulkan defisit anggaran.

\section{METODE PENELITIAN}

Penelitian ini adalah penelitian kuantitatif dengan pendekatan deskriftif. Metode ini disebut kuantitatif karena data penelitian berupa angka-angka dan analisis menggunakan statistik (Morissan, 2012). Populasi dalam penelitian ini adalah keseluruhan data jumlah penduduk, pengeluaran pemerintah serta pertumbuhan ekonomi Sumatera Utara sejak tahun 1948 sampai 2017. Sedangkansampelnyamulaitahun 1987 sampai 2017, jadi jumlah 
sampel yang ditarik dalam penelitian ini berjumlah 31 sampel. Teknik yang dilakukan dalam penentuan sampel yaitu teknik purposive sampling, yaitu teknik penentuan sampel dengan pertimbangan khusus sehingga layak dijadikan sampel. Adapun pertimbangan khususnya yaitu, Data yang tersedia dari jumlah penduduk dan pengeluaran pemerintah serta pertumbuhan ekonomi di Provinsi Sumatera Utara yang di publikasikan melalui Badan Pusat Statistik hanyamulai tahun 1987 sampai 2016 sebanyak 30 tahun. Data yang dipublikasi link Badan Pusat Statistik yaitu www.bps.go.id mengenai jumlah penduduk dan pengeluaran pemerintah serta pertumbuhan ekonomi di Provinsi Sumatera Utara hanyamulai tahun 1987 sampai 2016 sebanyak 30 tahun. Data yang digunakan berupa data sekunder yang diperoleh dari publikasi BPS atau BadanPusat Statistik Sumatera Utara di laman websidenya www.bps.go.id mulai tahun 1987 sampai 2016.

Setelah data yang terkumpul dianggap layak untuk diproses, selanjutnya dilakukan analisis data, dalam penelitian ini data dianalisis menggunakan bantuan program komputer SPSS versi 23. Teknik analisis data merupakan cara menganalisis data penelitian, termasuk alat-alat statistik yang relevan digunakan dalam penelitian. Adapun teknik analisis data yang digunakan sebagai berikut:

Statistik deskriptif adalah statistik yang digunakan untuk menganalisis data dengan cara menggambarkan data yang telah terkumpul. Statistik deskriptif juga dilakukan untuk mencari kuatnya hubungan antara variabel melalui analisis korelasi, melakukan prediksi dengan analisis regresi, dan membuat perbandingan dengan membandingkan rata-rata sampel atau populasi (Sugiyono, 2010).

Uji normalitas dilakukan untuk mengetahui apakah data yang diambil berasal dari populasi yang berdistribusi normal atau tidak. Teknik yang digunakan untuk menguji normalitas data antara lain dengan teknik kolmogrov-smirnov, yakni sama-sama menguji normalitas data yang disajikan secara individu (Juliansyah Noor, 2011). Dalam penelitian ini uji normalitas yang digunakan adalah uji K-S (Kolmogrov-Smirnov).

Uji Multikolinearitas yaitu mencari apakah ada hubungan linear yang sempurna atau pasti diantara beberapa atau semua variabel penjelas dari model regresi ganda (Setiawan dan Dwi Endah Kusrini, 2010). Untuk melihat adanya keberadaan multikolinieritas, salah satunya dengan cara melihat nilai VIF (Variance Inflation Faktor) dan Tolerance-nya. Jika nilai VIF kurangdari 10 dan nilai Tolerance lebih dari o,10 maka dapat disimpulkan bahwa dalam model yang diteliti tidak terjadi masalah multikolinearitas (Kurnia Maharani, dkk, 2014).

Salah satu asumsi regresi linear yang harus dipenuhi adalah homogenitas variansi dari error. Homokedastisitas berarti bahwa varians dari error bersifat konstan atau disebut 
juga identik. Kebalikannya adalah kasus heterokedastisitas yaitu jika kondisi varians errornya tidak identik (Setiawan dan Dwi Endah Kusrini, 2010). Ada beberapa metode yang telah dikemukakan untuk menguji kehadiran situasi Heteroskedasitas antara lain. metode park, metode glejser, metode Gold feld-Quandt dan metode Spearman rank korelation (Sritua, 1993). Untuk mempermudah hasil analisis dalam penelitian ini uji heteroskedastisitas yang digunakan adalah uji Glejser.

Uji Autokorelasi, autokorelasi dalam konsep regresi linear berarti komponen error berkorelasi berdasarkan urutan waktu atau urutan ruang, atau korelasi pada dirinya sendiri. Ada hal-hal lain yang sering menjadi penyebab autokorelasi diantaranya: tidak diikut sertakannya seluruh variabel bebas yang relevan dalam model regresi yang diduga, kesalahan menduga bentuk matematika model yang digunakan, pengolahan data yang kurang baik. Uji ada tidaknya autokorelasi yang paling banyak digunakan adalah Uji Durbin Watson (Uji $D W)$ (Sritua, 1993).

Analisis Regresi Berganda Model yang digunakan dalam penelitian ini adalah analisis regresi berganda dengan formula sebagai berikut:

$$
\mathrm{PE}=\mathrm{a}+\mathrm{b}_{1} \mathrm{JP}+\mathrm{b}_{2} \mathrm{PP}+\mathrm{e}
$$

Dimana:

$$
\begin{array}{ll}
\mathrm{PE} & =\text { Pertumbuhan Ekonomi } \\
\mathrm{a} & =\text { Konstanta } \\
\mathrm{b}_{1} & =\text { Koefisien untuk variabel jumlah penduduk } \\
\mathrm{b}_{2} & =\text { Koefisien untuk variabel pengeluaran pemerintah } \\
\mathrm{e} & =\text { Tingkat kesalahan } \\
\mathrm{JP} & =\text { Jumlah penduduk } \\
\mathrm{PP} & =\text { Pengeluaran pemerintah (Sritua Arief, 1993). }
\end{array}
$$

Uji Signifikansi Simultan (Uji F), dalam pengujian akan dilihat apakah semua variabel bebas secara bersama-sama mempengaruhi variabel terikat. Pengujian ini dilakukan dengan distribusi F. Signifikansi pengujian ini secara langsung dapat dilihat dari besarnya angka probabilitas. Jika p-value ( $\mathrm{F}$ statistik) lebih kecil dari $\alpha(\alpha=5 \%$ atau 0,05$)$ maka seluruh variabel bebas secara bersama-sama berpengaruh secara signifikan terhadap variabel terikatnya, dan begitu juga sebaliknya.

Uji Koefisien Determinasi $\left(\mathrm{R}^{2}\right)$, Koefisien determinasi $\left(\mathrm{R}^{2}\right)$ digunakan untuk mengetahui sampai sejauh mana ketepatan atau kecocokan garis regresi yang terbentuk dalam mewakili kelompok data hasil observasi. Koefisien determinasi menggambarkan bagian dari varians total yang dapatditerangkan oleh model. Semakin besar nilai $\mathrm{R}^{2}$ atau mendekati1, maka ketepatannya dikatakan semakin baik. Sifat yang dimiliki koefisien determinasi adalah nilai $\mathrm{R}^{2}$ selalu positif karena merupakan nisbah dari jumlah kuadrat nilai 
$\mathrm{O}<\mathrm{R}^{2}<1 . \mathrm{R}^{2}=\mathrm{O}$, berarti tidak ada hubungan antara $\mathrm{X}$ dan $\mathrm{Y}$ atau model regresi yang terbentuk tidak tepat untuk meramalkan $\mathrm{Y} . \mathrm{R}^{2}=1$, garis regresi yang terbentuk dapat meramalkan Y secara sempurna (Setiawan dan Dwi Endah Kusrini, 2010).

Uji Parsial (Uji T) Analisis statistik secara parsial digunakan untuk melihat signifikansi dari masing-masing variabel bebas secara individual dalam menjelaskan variabel terikat pada model dengan menggunakan uji t, dimana hipotesis nol (Ho: $\beta=0)$ artinya nilai koefisien sama dengan nol, sedangkan hipotesis altenatif $(\mathrm{H} 1: \beta \neq 0)$ artinya nilai koefisien berbeda dengan nol.

\section{HASIL DAN PEMBAHASAN}

\section{Deskriptif Statistik}

Analisis deskriptif digunakan untukmenggambarkan data yang telah terkumpul untuk membuat kesimpulan yang berlakuumum atau generalisasi. Statistik deskriptif juga dilakukan untuk mencari kuatnya hubungan antara variabel melalui analisis korelasi, melakukan prediksi, dengan analisis regresi, dan membuat perbandingan dengan membandingkan rata-rata data sampel dan populasi. Adapun analisis deskriptif dalam penelitian ini menggunakan menu deskriptif dengan hasil sebagai berikut:

Tabel .1

Hasil Analisis Deskriptif

\begin{tabular}{|l|r|r|r|}
\hline & \multicolumn{1}{|c|}{ Mean } & Std. Deviation & \multicolumn{1}{c|}{ N } \\
\hline ln_pertumbuhan_ekonomi & 18.1748 & .56974 & 30 \\
ln_jumlah_penduduk & 16.2925 & .10185 & 30 \\
ln_pengeluaran_pemerinta & 14.0241 & 1.23737 & 30 \\
h & & & \\
\hline
\end{tabular}

Sumber: Output SPSS versi 23, data diolah

Dari hasil output di atas dapat di lihat nilai pertumbuhan ekonomi Sumatera Utara dengan jumlah data $(\mathrm{N})$ sebanyak 30 tahun adalah 18.1748 dengan standar deviasi 0.56974. Sedangkan nilai dari variabel jumlah penduduk dengan jumlah data sebanyak 30 memiliki nilai mean sebesar 16,2925 dan nilai standar deviasi sebesar 0.10185. Dan variabel pengeluaran pemerintah mempunyai nilai mean sebesar 14. 0241 dengan standar deviasi sebesar 1.23737. Berdasarkan gambaran tersebut keseluruhan data sampel yang berhasil dikumpulkan telah memenuhi syarat untuk diteliti.

Penggunaan uji normalitas dilakukan untuk mengetahui apakah sampel yang diambil berdasarkan dari populasi berdistribusi normal atau tidak. Uji normalitas dlam penelitian ini 
dilakukan dengan uji Kolmogorov Smirnov (KS) dengan nilai p dua sisi (two tailed). Hal tersebut dapat dilihat pada tabel di bawah ini:

Tabel.2

Hasil Uji Normalitas Kolmogrov-Smirnov (K-S)

\begin{tabular}{|ll|r|r|r|}
\hline & & $\begin{array}{r}\text { ln_pertumbuhan } \\
\text { _ekonomi }\end{array}$ & $\begin{array}{c}\text { ln_jumlah } \\
\text { penduduk }\end{array}$ & $\begin{array}{r}\text { ln_pengeluaran } \\
\text { _pemerintah }\end{array}$ \\
\hline $\mathrm{N}$ & Mean & 30 & 30 & 30 \\
& Std. & 18.1748 & 16.2925 & 14.0241 \\
& Deviation & .56974 & .10185 & 1.23737 \\
Most Extreme Differences & Absolute & .076 & .103 & .127 \\
& Positive & .076 & .061 & .127 \\
& Negative & -.061 & -.103 & -.096 \\
Test Statistic & & .076 & .103 & .127 \\
Asymp. Sig. (2-tailed) & & $.200^{\mathrm{c}, \mathrm{d}}$ & $.200^{\mathrm{c}, \mathrm{d}}$ & $.200^{\mathrm{c}, \mathrm{d}}$ \\
\hline
\end{tabular}

Sumber: Output SPSS versi 23, data diolah

Kriteria yang digunakan dalam pengujian ini adalah apabila hasil perhitungan uji Kolmogrov-Smirnov dengan dua sisi lebih besar dari tingkat signifikan $5 \%(0,05)$, maka data berdistribusi normal. Dari hasil output di atas dapat disimpulkan bahwa nilai signifikan pertumbuhan ekonomi sebesar $0.20>0.05$, berarti variabel pertumbuhan ekonomi berdistribusi normal. Kemudian nilai signifikan dari variabel jumlah penduduk sebesar 0.20 > 0.05, dapat dinyatakan bahwa jumlah penduduk berdistribusi normal. Sedangkan nilai signifikan pengeluaran pemerintah $0.20>0.05$, dengan itu variabel-variabel tersebut dinyatakan berdistribusi normal sehingga dapat memenuhi syarat untuk uji parametrik.

Uji multikolinearitas dilakukan untuk melihat apakah ada hubungan linear yang sempurna atau pasti diantara beberapa atau semua variabel penjelas dari model regresi ganda. Uji multikolinearitas dalam penelitian ini menggunakan kriteria pengujian pada nilai tolerance dan VIF. 
Tabel.3

Hasil Uji Multikolinearitas

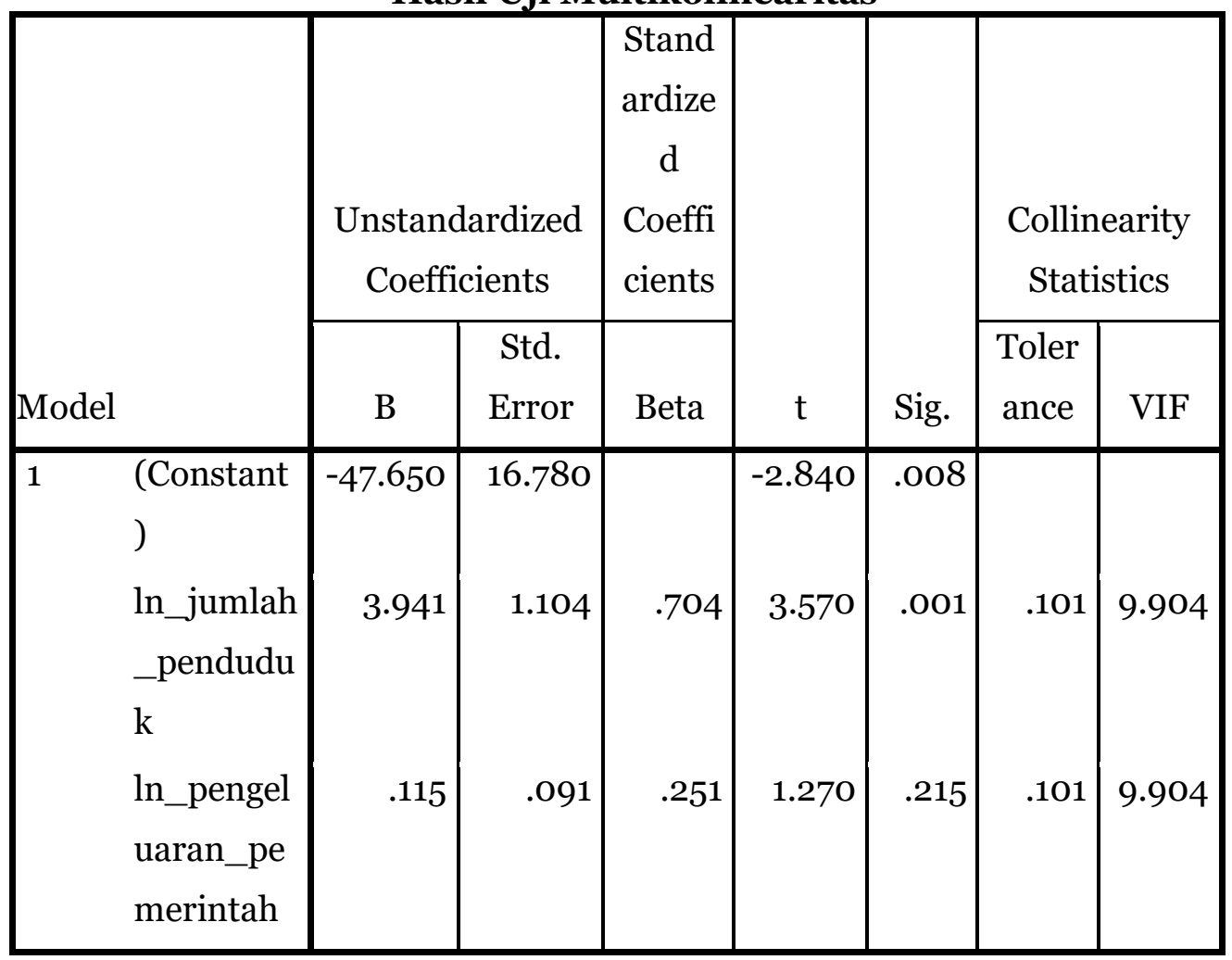

Sumber: Output SPSS versi 23, data diolah

Dari hasil output di atas dapat dinyatakan hipotesis dari uji multikolinieritas sebagai berikut: Melihat nilai Tolerance: Jika nilai Tolerance $>0.10$ berarti tidak terjadi gejala multikolinieritas terhadap data yang diuji. Dan sebaliknya. Melihat nilai VIF (Variance Inflation Faktor): jika nilai VIF < 10.00 maka tidak terjadi Multikolinieritas terhadap data yang diuji, begitu sebaliknya. Dapat disimpulkan bahwa nilai tolerance dari tabel diatas $0.101>0.10$, berarti tidak terdapat gejala multikolinearitas. Sedangkan nilai VIF dari hasil output tersebut adalah $9.904<10.00$, maka tidak terjadi multikolinieritas dalam data yang diuji.

Uji Homokedastisitas dilakukan untuk melihat apakah varians dari error bersifat konstan atau disebut juga identik. Regresi yang baik seharusnya tidak terjadi heterokedastisitas. Uji multikolinearitas dalam penelitian ini menggunakan uji Glejser yang dilakukan dengan cara meregresikan antara variabel independen dengan nilai absolut residual (Imam Ghozali, 2013).Untuk lebih jelasnya dapat dilihat pada tabel di bawah ini: 
Tabel. 4

Hasil Uji Heteroskedstisitas

\begin{tabular}{|c|c|c|c|c|c|}
\hline & \multicolumn{2}{|c|}{$\begin{array}{c}\text { Unstandardized } \\
\text { Coefficients }\end{array}$} & $\begin{array}{r}\text { Standardize } \\
\mathrm{d} \\
\text { Coefficients }\end{array}$ & & \\
\cline { 2 - 5 } Model & $\mathrm{B}$ & $\begin{array}{c}\text { Std. } \\
\text { Error }\end{array}$ & Beta & $\mathrm{t}$ & Sig. \\
\hline $\begin{array}{c}\text { (Constant) } \\
\text { ln_jumlah_penduduk } \\
\text { ln_pengeluaran_pem } \\
\text { erintah }\end{array}$ & .71 .567 & 12.396 & .033 & .359 \\
& .002 & .067 & .014 & .026 & .979 \\
\hline
\end{tabular}

Sumber: Output SPSS versi 23, data diolah

Dari hasil output di atas, uji heteroskedastisitas yang dilakukan dengan menggunakan uji Glejser dapat diketahui bahwa nilai signifikansi variabel jumlah penduduk sebesar $0.389>0.05$, maka tidak terjadi masalah heterokedastisitas. Sedangkan nilai signifikan dari pengeluaran pemerintah sebesar $0.979>0.05$ dengan itu variabel tersebut tidak memiliki masalah heterokadastisitas.

Uji Autokorelasi bertujuan menguji apakah dalam model regresi linear ada korelasi antara kesalahan pengganggu pada periode $t$ dengan kesalahan pengganggu pada periode periode sebelumnya. cara yang dapat digunakan untuk menguji autokorelasi dalam penelitian ini menggunakan uji Durbin-Watson (D-W) (Imam Ghozali, 2013).

Tabel.5

Hasil Uji Autokorelasi Uji D-W

\begin{tabular}{|l|r|r|r|r|r|}
\hline Model & \multicolumn{1}{|c|}{$\mathrm{R}$} & R Square & $\begin{array}{c}\text { Adjusted R } \\
\text { Square }\end{array}$ & $\begin{array}{c}\text { Std. Error of } \\
\text { the Estimate }\end{array}$ & $\begin{array}{c}\text { Durbin- } \\
\text { Watson }\end{array}$ \\
\hline 1 & $.945^{\mathrm{a}}$ & .894 & .886 & .19237 & 1.208 \\
\hline
\end{tabular}

Sumber: Output SPSS versi 23, data diolah

Dari hasil output di atas dapat dilihat bahwa nilai DW sebesar 1,208 dengan menggunakan derajat kepercayaan 5\% (0.05), dan jumlah sampel sebesar 30 dengan jumlah variabel bebas sebanyak 2. Dengan menggunakan perbandingan pada nilai tabel Durbin Watson (D-W) di peroleh nilai $d_{L}=1,284$ dan nilai $d_{U}=1,567$. Dengan perolehan dari nilai $4-$ $1,208>1,567$ atau 2,792 >1,567. Dengan demikian dapat disimpulkan bahwa data yang di uji tidak terjadi masalah autokorelasi. Untuk lebih jelasnya dapat di lihat pada bagan di bawah ini: 


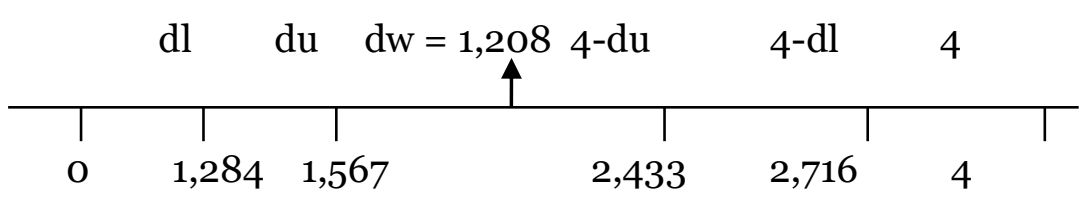

Analisis regresi linear berganda digunakan untuk mengetahui pengaruh atau hubungan secara linier antara dua atau lebih variabel independen dengan satu variabel dependen. Untuk lebih jelasnya tebel di bawah menggambarkan hasil dari analisis regresi berganda:

Tabel.6

Hasil Analisis Regresi Berganda

\begin{tabular}{|c|c|c|c|c|c|}
\hline \multirow[b]{2}{*}{ Model } & \multicolumn{2}{|c|}{$\begin{array}{c}\text { Unstandardized } \\
\text { Coefficients }\end{array}$} & $\begin{array}{l}\text { Standardi } \\
\text { zed } \\
\text { Coefficie } \\
\text { nts }\end{array}$ & & \\
\hline & B & $\begin{array}{l}\text { Std. } \\
\text { Error }\end{array}$ & Beta & $\mathrm{t}$ & Sig. \\
\hline $1 \quad$ (Constant) & -47.650 & 16.780 & & $\begin{array}{r}- \\
2.84 \\
0\end{array}$ & .008 \\
\hline $\begin{array}{l}\text { ln_jumlah_pendud } \\
\text { uk } \\
\text { ln_pengeluaran_pe } \\
\text { merintah }\end{array}$ & $\begin{array}{r}3.941 \\
.115\end{array}$ & 1.104 & .704 & $3 \cdot 570$ & .001 \\
\hline
\end{tabular}

Sumber: Output SPSS versi 23, data diolah

Berdasarkan hasil analisis di atas maka dapat dibuat model persamaan regresinya sebagai berikut:

$$
\begin{aligned}
& \mathrm{PE}=\mathrm{a}+\mathrm{b} 1 \mathrm{JP}+\mathrm{b} 2 \mathrm{PP} \\
& \mathrm{PE}=-47,650+3,941 \mathrm{JP}+0,115 \mathrm{PP}
\end{aligned}
$$

Dari model persamaan di atas dapat di simpulkan analisis dari penelitian ini adalah sebagai berikut: Nilai konstanta sebesar $-47,650$ berarti nilai dari pertumbuhan ekonomi adalah sebesar -47,650. Jika dianggap nilai jumlah penduduk dan pengeluaran pemerintah adalah nol (o) atau konstan. Nilai koefisien 3,941 berarti jika nilai jumlah penduduk bertambah satu satuan, sedangkan pengeluaran pemerintah di anggap nol atau konstan 
maka nilai dari pertumbuhan ekonomi akan bertambah sebesar 0,025 satu satuan. Nilai koefisien 0,115 ini berarti jika koefisien nilai pengeluaran pemerintah bertambah satu satuan, sedangkan jumlah penduduk dianggap nol maka nilai pertumbuhan ekonomi akan bertambah sebesar 0,115 satu satuan.

Uji signifikansi simultan merupakan uji yang dilakukan untuk melihat apakah semua variabel bebas secara bersama-sama mempengaruhi variabel terikat. Pengujian ini dilakukan dengan membandingkan nilai $\mathrm{F}$ hitung dengan nilai $\mathrm{F}$ tabel. Untuk lebih jelasnya hasil uji tersebut dapat dilihat pada tabel di bawah ini:

Tabel. 7

Hasil Uji Signifikansi Simultan (F)

\begin{tabular}{|l|r|r|r|r|l|}
\hline Model & \multicolumn{1}{|c|}{$\begin{array}{c}\text { Sum of } \\
\text { Squares }\end{array}$} & Df & \multicolumn{1}{c|}{$\begin{array}{c}\text { Mean } \\
\text { Square }\end{array}$} & \multicolumn{1}{c|}{ F } & Sig. \\
\hline Regression & 8.414 & 2 & 4.207 & 113.692 & $.000^{\mathrm{b}}$ \\
Residual & .999 & 27 & .037 & & \\
Total & 9.414 & 29 & & & \\
\hline
\end{tabular}

Sumber: Output SPSS versi 23, data diolah

Dari hasil output di atas hipotesis uji F dapat dinyatakan sebagai berikut: Jika nilai $\mathrm{F}$ hitung $>\mathrm{F}$ tabel atau nilai signifikansi $<0.05$, maka variabel $\mathrm{X}$ berpengaruh terhadap variabel Y. Jika nilai F hitung $<\mathrm{F}$ tabel atau nilai signifikansi > 0.05, maka variabel X tidak berpengaruh terhadap variabel Y. Dari tabel di atas dapat dilihat nilai F hitung sebesar 113. 692, sedangkan nilai $\mathrm{F}$ tabel diperoleh dengan menggunakan tabel $\mathrm{F}$, dengan df penyebut yaitu 27 dan df pembilang yaitu 2 dengan taraf signifikansi 0.05 sehingga diperoleh nilai $\mathrm{F}$ tabel sebesar 3. 35. Jadi karena nilai $F_{h}(113.692)>F_{t}(3.35)$ atau nilai Sig $(0.000)<0.05$ maka secara bersamaan variabel jumlah penduduk dan pengeluaran pemerintah pengaruh signifikan terhadap pertumbuhan ekonomi.

Uji Koefisien Determinasi atau yang sering disebut juga uji R square $\left(\mathrm{R}^{2}\right)$ digunakan untuk mengetahui sampai sejauh mana ketepatan atau kecocokan garis regresi yang terbentuk dalam mewakili kelompok data hasil observasi. Koefisien determinasi menggambarkan bagian dari varians total yang dapat diterangkan oleh model. Untuk lebih jelasnya hasil uji $\mathrm{F}$ tersebut dapat dilihat pada tabel di bawah ini:

Tabel. 8

Hasil Uji Koefisien Determinasi $\left(\mathbf{R}^{2}\right)$

\begin{tabular}{|l|c|c|c|c|}
\hline Model & $\mathrm{R}$ & R Square & $\begin{array}{c}\text { Adjusted R } \\
\text { Square }\end{array}$ & $\begin{array}{c}\text { Std. Error of } \\
\text { the Estimate }\end{array}$ \\
\hline 1 & $.945^{\mathrm{a}}$ & .894 & .886 & .19237 \\
\hline
\end{tabular}

Sumber: Output SPSS versi 23, data diolah 
Berdasarkan hasil output di atas, dapat di lihat besarnya hubungan antara variabel jumlah penduduk dan pengeluaran pemerintah secara simultan terhadap pertumbuhan ekonomi di lihat pada nilai R sebesar 0945 yang menunjukkan terdapat hubungan yang kuat. Dengan nilai R square sebesar 89 persen menunjukkan kontribusi secara bersama-sama dari variabel jumlah penduduk dan pengeluaran pemerintah, sedangkan 11 persen dipengaruhi oleh variabel lain yang tidak dimasukkan dalam model penelitian ini.

Uji Parsial (Uji t), Analisis statistik secara parsial digunakan untuk melihat signifikansi dari masing-masing variabel bebas secara individual dalam menjelaskan variabel terikat pada model. Deengan kata lain uji ini dilakukan untuk melihat keterkaitan masingmasing variabel bebas terhadap variabel terikat. Tabel berikut akan menggambarkan hasil dari uji parsial (uji t):

Tabel. 9 Hasil Uji Parsial (uji t)

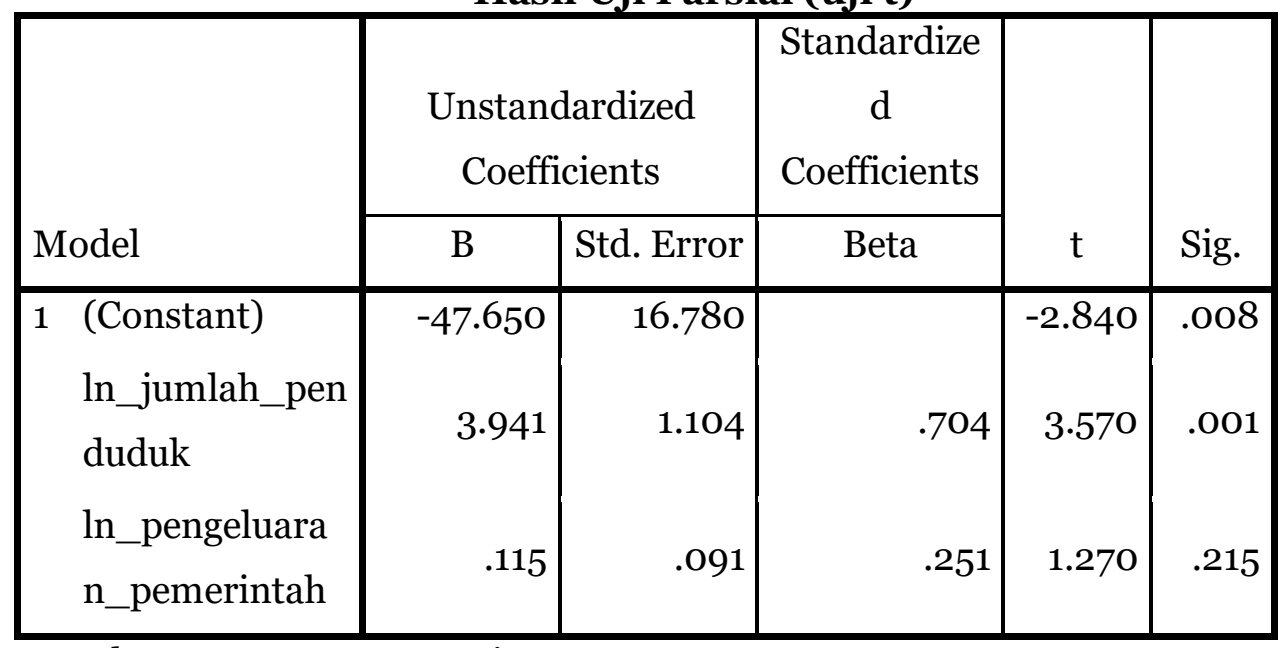

Sumber: Output SPSS versi 23

Dari hasil output di atas dapat disimpulkan bahwa hipotesis dalam penelitian ini adalah sebagai berikut: Jika nilai $\mathrm{T}$ hitung <= Ttabel atau nilai probabilitas (Sig) > 0.05 maka $\mathrm{H}_{\mathrm{o}}$ Diterima. Jika nilai $\mathrm{T}$ hitung $>\mathrm{T}$ tabel atau nilai probabilitas (Sig) $<0.05$ maka $\mathrm{H}_{\mathrm{o}}$ Ditolak. Pada variabel jumlah penduduk dari tabel di atas dapat di lihat bahwa nilai T hitung (3.570) > T tabel (2. 053) atau sig (0.001) < 0.05, maka $\mathrm{H}_{\mathrm{o}}$ ditolak, yang berarti jumlah penduduk berpengaruh signifikan terhadap pertumbuhan ekonomi. Sedangkan pada variabel pengeluaran pemerintah nilai $\mathrm{T}$ hitung $(1.270)<\mathrm{T}$ tabel $(2.053)$ atau sig $(0.215)>0.05$, maka $\mathrm{H}_{\mathrm{o}}$ diterima yang berarti pengeluaran pemerintah secara parsial tidak berpengaruh signifikan terhadap pertumbuhan ekonomi. 


\section{KESIMPULAN}

Jumlah penduduk secara parsial berpengaruh terhadap pertumbuhan ekonomi, hal ini dibuktikan dengan melihat nilai $\mathrm{t}_{\mathrm{h}}(3.570)>\mathrm{t}_{\mathrm{t}}$ (2. 053) atau sig (0.001) < 0.05 maka $\mathrm{H}_{01}$ ditolak dan $\mathrm{H}_{\mathrm{a} 1}$ diterima.Pengeluaran pemerintah tidak berpengaruh secara parsial terhadap pertumbuhan ekonomi, hal tersebut dibuktikan dengan melihat nilai $t_{\text {hitung }}(1.270)<t_{\text {tabel }}(2$. 053) atau sig (0.215) > 0.05 sehingga $\mathrm{H}_{\mathrm{o} 2}$ diterima maka $\mathrm{Ha}_{2}$ ditolak dan Jumlah penduduk dan pengeluaran pemerintah berpengaruh secara simultan terhadap pertumbuhan ekonomi, pernyataan ini dibuktikan dengan nilai $F_{h}(113.692)>F_{t}(3.35)$ atau nilai Sig $(0.000)<0.05$ maka $\mathrm{H}_{03}$ ditolak dan $\mathrm{H}_{\mathrm{a} 3}$ diterima.

\section{DAFTAR PUSTAKA}

BPS Sumut, 2016,www.bps.go.id. Medan, Sumut

Chapra, M. Umer, 2013,Islam dan Tantangan Ekonomi, Diterjemah dari "Islam And The Economic Challenge” oleh Ikhwan Abidin Basri,Jakarta, GemaInsani.

Ghozali, Imam, 2013,Aplikasi Analisis Multivariate dengan Program IBM SPSS 21. Semarang, BadanPenerbitUniversitasDiponegoro.

Kusrini, Dwi, Endah, Setiawan, 2010,Ekonometrika, Yogyakarta, Andi.

Morissan, 2012,Metode Penelitian Survei, Jakarta, Kencana.

Maharani, Kurniadkk, 2014,Kajian Investasi, Pengeluaran Pemerintah, Tenaga Kerja dan Keterbukaan Ekonomi terhadap Pertumbuhan Ekonomi di Provinsi Jawa Tengah“, dalam Jurnal Bisnis dan Ekonomi, Volume 21, No. 1. Jakarta,

Putong, Iskandar, 2013,Pengantar Mikro dan Makro,Jakarta, MitraWacana Media.

Sumut, Medan, 2017,http://m.gosumut.com, http://m.gosumut.com

Sugiyono, 2010,Metode Penelitian Kuantitatif, Kualitatif dan R\&D,Bandung, Alfabeta. 